O. O. Kylymenchuk, PhD Technical Sciences, Associate Professor, T. O. Velichko, PhD Technical Sciences, Associate Professor, A.A. Umanets, A.D. Gnilichenko, H.O. Prodanova, Bachelor degree students, Faculty of Wine Technology and Travel Business Odessa National Academy of Food Technologies, Odessa (Ukraine)

\title{
STUDY OF INDIVIDUAL BIOTECHNOLOGICAL ASPECTS OF WHEAT DOUGH FERMENTATION PROCESS
}

\section{Abstract}

The article presents the results of the study of behavior of Saccharomyces cerevisiae yeast cells during the fermentation of wheat dough with different vegetable oils, namely amaranth, sunflower and corn. The calculation of yeast cells and the study of their physiological characteristics were carried out at different stages of the process of fermentation of wheat flour bread. The dynamics of changes in acidity in the fermentation process and the maturation of the dough were investigated by the titrimetric method.

The study results indicate that the process of adaptation of the yeast cell to the nutrient medium in the presence of amaranth oil is faster compared to corn and sunflower vegetable oils. The components of amaranth oil increase the fermentation activity of Saccharomyces cerevisiae yeast. Due to the action of active ingredients of amaranth oil, the process of yeast activation is much faster, the mechanisms of self-regulation and self-recovery are initiated, the process of fermentation and maturation is shorter, and the quality of straight-dough bread improves. Activation of yeast cells during fermentation of dough with addition of amaranth oil is possible due to saturation of the nutrient medium with additional oxygen due to squalene, which acts at the beginning of the process of cell adaptation to the nutrient medium. In such environment, the mechanisms of self-regulation and self-recovery are activated much faster.

In addition to squalene, amaranth oil contains a rare tocotrienol form of vitamin $E$, which can increase the elasticity of cell walls, permeability of substances into the cell and the removal of metabolites from it, which accelerates the metabolic processes.

Bioactive substances of amaranth oil considerably enrich the nutrient medium and have a positive effect on the development of nutrient medium-sensitive lactic acid microorganisms, which accelerates the dough maturation processes. The dough maturation process is reduced by 20 minutes.

Usage of activated amaranth oil allows to improve individual organoleptic characteristics of bread. The dosage of amaranth oil has been optimized and a formula of wheat flour bread has been developed.

Key words: yeast, fermentation, acidity, vegetable oils, amaranth, squalene, nutrient medium, activation.

\section{Introduction}

Under market relations, the key task of any manufacture, including food, is to produce competitive products. One of the methods to solve this problem can be the use of wasteless energy-saving technologies which allow to obtain high-quality products at low energy expenditures for producing them.

The most long-lasting stage in producing foods from yeast-fermented dough is the fermentation process. It is a biotechnological stage when it is possible to influence the main biological agent - the yeasts - and to shorten the process of dough maturation in general. The Saccharomyces cerevisiae yeasts are known to possess the ability to ferment saccharides in an oxygen-deficient medium and to oxidize them via respiration when enough oxygen is present. They ferment and utilize glucose, galactose, sucrose, maltose, partly raffinose and simple dextrins of malt wort. They do not ferment and do not utilize lactose, pentoses (xylose, arabinose), starch, and cellulose. The source of nitrogen in the dough used by yeasts is amino acids. The optimum temperature is $30^{\circ} \mathrm{C}$. Only some particular cultures can resist temperatures of $35-37^{\circ} \mathrm{C}$. The yeasts of this species resist well a medium acidity of $10-12^{\circ} \mathrm{T}$. The optimum $\mathrm{pH}$ for them ranges between 4.5 and 5 . Adding sugar (above 15\%) or salt (above 1-1.5\%) to the medium makes negative impact on the yeasts' life activity. Ethyl alcohol in concentrations of $2-5 \%$ inhibits their development. In the presence of $12-14 \%$ alcohol the fermentation stops in most cases. The negative impact of alcohol increases as the tempera- ture rises $[1,2]$.

Yeast-fermented dough from wheat flour is prepared in two main ways: straight and sponge. In the straight type, all ingredients included in the formula and water are introduced during kneading simultaneously. The initial temperature of the dough is 28 to $30^{\circ} \mathrm{C}$. The fermentation, depending on the quality and amount of yeasts, lasts for $2-4$ hours. 1.5 to $2.5 \%$ yeasts are added to the straight dough, depending on their quality and desired duration of fermentation (expenditure of liquid yeasts is $40-50 \%$ ). The sponge type includes two stages: preparation of the starter and preparation of the dough. The starter preparation takes about half the entire amount of flour, up to $2 / 3$ of water and all of the yeasts listed in the formula. Salt is not added to the starter in most cases. The expenditure of yeasts for sponge dough is about twice smaller than that for straight dough. The initial temperature of the starter is $28-30^{\circ} \mathrm{C}$. The starter's fermentation duration is 3 to 4.5 hours. The fermented starter is used to knead the dough with adding the remaining flour and water, and salt in a solution. The initial temperature of the dough is 28 to $30^{\circ} \mathrm{C}$. The fermentation lasts for 60 to 105 minutes.

Each of these methods has its advantages and disadvantages. The advantages of sponge method include the fact it makes the quality of bread higher compared to straight-dough baking. Better physical properties of the sponge dough result in a good crumb vesiculation and its high volume yield.

A higher accumulation of lactic acid also pro- 
mote better physical and flavor properties of the dough. Using liquid starters allows to automate the process entirely and to proceed to continuous technological lines [1, 2].

The advantages of the straight-dough method include shorter fermentation duration, less manufacturing area and technological equipment required and less dry matter of the flour expended. Economical advantages of the straight-dough method are very significant compared to sponge-dough bread baking $[1,2]$.

The dough fermentation starts from the beginning of kneading and lasts as long as the dough stays in the fermentation tanks and continues during the following technological operations.

Fermentation is the accumulation of flavor substances in the intermediate products and in the dough, and giving the dough gas-retaining and physical properties required during processing and baking.

During the final stages of the manufacture proofing of the dough pieces and baking - the main goal of the fermentation is loosening of the dough by the carbon dioxide and formation of crumb with a welldeveloped thin-wall vesiculation.

The summary of all processes resulting in optimum dough properties for processing and baking is termed the dough maturation.

The dough maturation includes alcohol fermentation, development of acid-producing bacteria with accumulation of organic acids, and colloid, physical and biochemical processes.

The alcohol fermentation is caused by yeasts and it results in convertion of saccharides into alcohol and carbon dioxide. The yeasts ferment first glucose and fructose and then sucrose and maltose, the latter previously converted into monosaccharides. The source of monosaccharides is the free monosaccharides from the grain that pass to the flour, but the bulk is maltose produced in the dough from degraded starch. The fermentation rate depends on the temperature, presence of monosaccharides, proteins, mineral substances and vitamins, and on the medium $\mathrm{pH}$ and the amount of yeasts.

Organic acids are produced as a result of lactic acid fermentation caused by lactic acid bacteria. There are two types of lactic acid bacteria: homofermentative, producing lactic acid, and heterofermentative, producing other organic acids, like acetic, formic, citric, succinic and other, besides the lactic acid [3]. Lactic acid accounts for about $70 \%$ of the total amount of acids in wheat dough. In rye dough, the contents of lactic and acetic acids are almost equal. When the moisture and temperature of the dough are lowered, heterofermentative lactic acid bacteria develop faster, resulting in a dramatic increase of the dough's acidity and deterioration of the bread's flavor $[1,2]$.

It is known from literature sources that an optimum temperature of the dough of 26 to $32^{\circ} \mathrm{C}$ is used to optimize and intensify the technological processes of the dough preparation in the industrial conditions. Many other ways of intensification of fermentation processes exist: increasing the amount of yeasts, previous activation of yeasts, electrophysical treatment of yeast suspension, magnetic treatment, introduction of mineral salts into the dough to "feed" yeasts, adding enzymes to com- pressed yeasts, introduction of substances impacting the activity of yeasts' enzymes (wastes of agricultural raw material processing, flour, flour brews, juices, grain extracts etc.). Some physical factors influence the morphological structures of the yeast cells, primarily the cytoplasmic membrane. These are ultrahigh-frequency magnetic currents, ultrasound, optical rays, elevated temperatures. They are frequently used in combinations.

In addition, the process of dough maturation can be significantly accelerated by intensive mechanical action and surface-active substances that influence the structural and mechanical properties of the dough, and also by oxidative (potassium bromate and iodate) or reductive (cysteine) accelerators that change the redox potential of the dough and therefore change its structural and mechanical properties $[1,2]$.

The vegetable oils included in many bread formulas include such components as polyunsaturated fatty acids, vitamins E and group B, steroids, phytosterols etc.

Today, large-tonnage manufactures of vegetable oils exist, including sunflower, maize, olive oils etc. Vegetable oils are important food products: they provide the human organism with energy and essential unsaturated fatty acids, and their functional properties are determined strongly by the composition of fatty acids present, degree of their unsaturation and balance between cis and trans-isomers and other substances $[3,4]$.

Due to this broad range of various natural biologically active components, natural oils can make combined impact both on the yeast cytoplasmic membrane (as the yeasts are the main fermenters) and on the redox potential of the medium and on structural and mechanical properties of the dough. Among the vast range of oils of low-tonnage manufacture, the amaranth oil is notable. It is obtained from the seeds of a herbaceous plant from Amaranthaceae family which comes from Central America.

The chemical composition of amaranth oil includes riboflavin (vitamin $\mathrm{B}_{2}$ ), tocopherol (vitamin $\mathrm{E}$ ), thiamine (vitamin $\mathrm{B}_{1}$ ), group $\mathrm{D}$ vitamins, provitamin $\mathrm{A}$, chlorophyll, choline, bile salts, steroids, phytosterols, and polyunsaturated fatty acids, especially unique in that they contain a well-balanced complex of omega-3 and omega6. This allows to use it to treat many diseases.

Amaranth oil is a well-known source of squalene. Squalene is the main component of human skin and a substance related to the human cell composition, it captures oxygen and saturates the tissues and organs with it by a simple chemical interaction with water in the cells. Amaranth oil contains 5 to $15 \%$ of squalene [5-8]. This is why we decided in its favor as a source of a wide complex of biologically active substances.

Taking the above mentioned into consideration, the goal of this work was:

- to accelerate and optimize the fermentation process of straight dough made from wheat flour by adding certain amounts of some oils of local manufacture at the beginning of kneading (sunflower, maize and amaranth oils as a spectrum of biologically active substances which can integrally impact the fermenters - the yeast cells);

- to optimize the dosage of amaranth oil for the given bread formula; 
- study the physiological performance and morphological features of Saccharomyces cerevisiae yeasts during fermentation;

- test the organoleptic characteristics of the final product after baking;

- estimate the shelf life of the baked bread.

In order to improve the flavor properties of the straight-dough bread, kefir was used in kneading all specimens.

\section{Materials and methods}

In order to study the performance of Saccharomyces cerevisiae yeast cells during the fermentation of wheat dough with various vegetable oils, the following oils were used: sunflower - "Oleyna", maize unrefined from first cold-press - TOV "Rassvetovskie masla" (TR U 10.4-36553354-001:2012), amaranth - "Amarant korolivskiy" cold-pressed in 2017 by SFG "Olena" (contains 7.5\% squalene, TR U 10.4-36553354-001-2012). Other ingredients: top-grade wheat flour "Amina. Dobra gospodynya” by TOV “Agro-Yug-Servis”, baker's yeasts compressed "Kryvorizki drizhdgi" by PrAT "Nadezhda", kefir "Selyanskyi" with $1 \%$ fat content by "Lustdorf" (TR U 25027034-011-99), salt, sugar and water.

The physiological condition of yeasts was studied using a method based on determination of rates between mature, dead and budding cells. The cells were counted in Goryayev's chambers and by direct microscopy in "flattened drop" mounts under 600x and 1350x magnifications, stained with methylene blue and Lugol's iodine [9]. Rinses were made with sterile water from dough samples of $1 \mathrm{~g}$ of each specimen. Then, serial tenfold dilutions of the rinses were made. The cells were counted with account of the dilution degree.

The dough acidity during fermentation was determined by dissolving $5 \mathrm{~g}$ of each dough specimen in 50 $\mathrm{ml}$ of distilled water with adding 2-3 drops of phenolphthalein and titrating with $0.1 \mathrm{~N} \mathrm{NaOH}$ until the solutions turned pink. The acidity was determined by the following formula:

$$
X=\frac{V \cdot V_{1} \cdot a \cdot K}{10 \cdot m \cdot V_{2}}
$$

where $V$ is the volume of molar concentration ( 0.1 mole/l) of $\mathrm{NaOH}$ expended for titrating,

$V_{1}$ is the volume of distilled water used for extracting acids from the specimen,

$V_{2}$ is the volume of sample taken for titration,

$a$ is a coefficient of convertion to $100 \mathrm{~g}$ weight,

$K$ is a correction coefficient of converting sodium or potassium hydroxide solution to the exact molar concentration of 0.1 mole/l.

$1 / 10$ is a coefficient to convert the $\mathrm{NaOH}$ or $\mathrm{KOH}$ solution of $0.1 \mathrm{~mole} / 1$ to $1.0 \mathrm{~mole} / 1$,

$m$ is the sample's weight.

The probationary baking and estimation of organoleptic features was made according to State standard GOST 27669-88.

\section{The body of the work.}

Four specimens of dough with compressed yeasts were kneaded according to the formula. Equal amounts of amaranth, maize and sunflower oils were added to three of them, and the fourth one was left as a control oil-free specimen. The diagram of the investigation is shown in fig. 1.

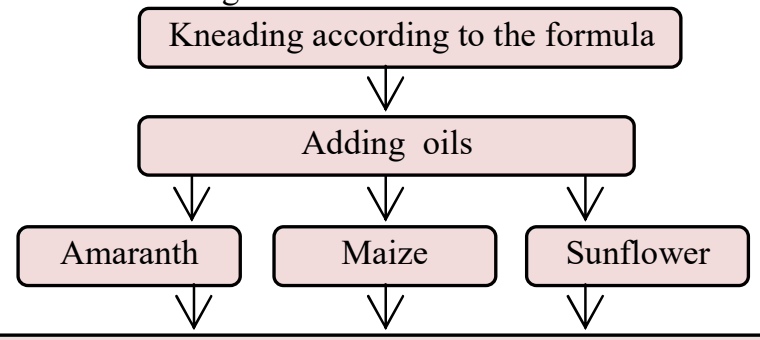

Providing optimum conditions for fermentation $\left(\mathrm{t}=30^{\circ} \mathrm{C}\right)$

$$
\bigvee
$$

Sampling the dough to determine the acidity, studying physiological properties

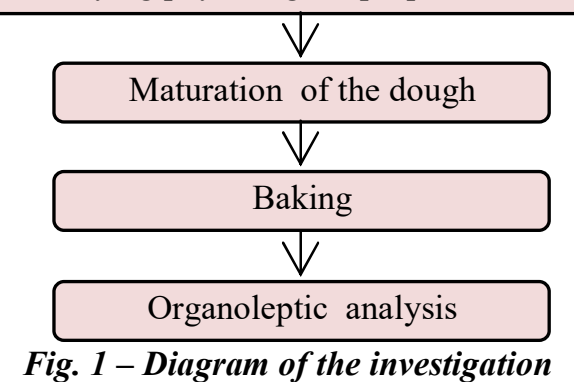

At regular intervals, physiological features of the yeasts were studied at each stage of fermentation by rinsing and making "flattened drop" mounts, and the fermentation process, maturation of the dough and the acidity were controlled. Also, the yeasts cells were counted in all specimens with the Goryayev's chambers. The investigation showed that the yeasts were almost physiologically identical in all specimens after 15 min of fermentation. In another $15 \mathrm{~min}$, the yeasts in the dough with amaranth oil had 10\% more budding cells. In other two specimens (with maize and sunflower oils) the cells were identical in size, but in the amaranth dough they were smaller, appeared more active, mother cells and daughter cells stayed together in an entire lawn and their generation time was 3 min shorter. In the amaranth specimen the dough maturation process ended 20 min earlier. This may have the following explanation.

At the yeasts manufactures, the yeasts are produced by air-intake (exponential feeding) method with large amounts of air blown through the nutrient medium. Therefore, the yeasts entering a bakery manufacture are respiration-type yeasts. In addition, the yeasts are stored refrigerated, resulting in that the cells go into anabiosis. In order to make the yeasts recover from anabiosis and switch from respiration to alcohol fermentation, they must be activated.

The yeast cells can be activated by saturating the nutrient medium with additional oxygen using squalene which acts at the beginning of adaptation of the cells to the nutrient medium. In this totally natural (for the cells) medium, the mechanisms of self-regulation and self-recovery are triggered faster.

Fig. 2 shows the results of counting yeast cells after $30 \mathrm{~min}$ of fermentation.

Table 1 describes the results of determination of titrated acidity of the dough during fermentation and maturation. 


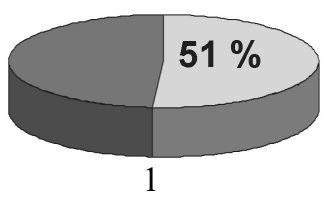

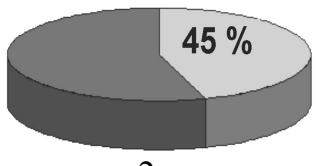

2

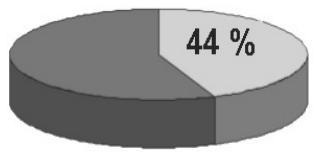

3

Fig. 2 - Proportion of budding yeast cells:

1 - with amaranth oil, 2 - with maize oil, 3 - with sunflower oil.

Table 1 - Results of determination of titrated acidity of the dough during fermentation and maturation

\begin{tabular}{||c||c||c||c||c||}
\hline \hline \multicolumn{1}{||c||}{} & \multicolumn{4}{|c||}{ Volume of titrant $(\mathrm{NaOH}), \mathrm{ml}$} \\
\hline \hline $\begin{array}{c}\text { Time, } \\
\text { min }\end{array}$ & $\begin{array}{c}\text { Specimen 1, } \\
\text { amaranth oil }\end{array}$ & $\begin{array}{c}\text { Specimen 2, } \\
\text { maize oil }\end{array}$ & $\begin{array}{c}\text { Specimen 3, } \\
\text { sunflower oil }\end{array}$ & $\begin{array}{c}\text { Control } \\
\text { (oil-free) }\end{array}$ \\
\hline \hline 15 & 2,0 & 2,0 & 2,0 & 2,0 \\
\hline \hline 45 & 2,4 & 2,1 & 2,1 & 2,1 \\
\hline \hline 75 & 2,7 & 2,5 & 2,4 & 2,3 \\
\hline \hline 105 & 3,0 & 2,7 & 2,7 & 2,5 \\
\hline \hline 135 & 3,5 & 2,7 & 2,8 & 2,6 \\
\hline \hline
\end{tabular}

by the specimen's resilience, volume and acidity.

After the process of dough fermentation was over, test specimens of bread were baked and tested organoleptically.

In the organoleptic test of all specimens, two bread specimens were conspicuous: the one with maize oil for a specific odor and the one with amaranth oil for uniform small pores in the crumb cut com-

These results show that yeasts started the fermentation faster in the specimen with amaranth oil. Accelerated increase of titrated acidity in this specimen indicates the accumulation of metabolites in the dough during fermentation. These metabolites together with other ingredients had optimized the nutrient medium and enhanced the symbiotic growth of fastidious lactic acid bacteria and yeasts, which, in turn, shortened the process of dough maturation compared to other specimens. The process of maturation was determined organoleptically, pared to others (fig. 3).

All specimens were tasty with characteristic crusts. The results of organoleptic tests of bread with various vegetable oils are summed up in table 2 .

Test baking of bread and its organoleptic characterization showed that the specimen with amaranth oil is as good as other two in external characteristics and is the best in the crumb structure. The process of staling in the specimen with amaranth oil started later than in other two.

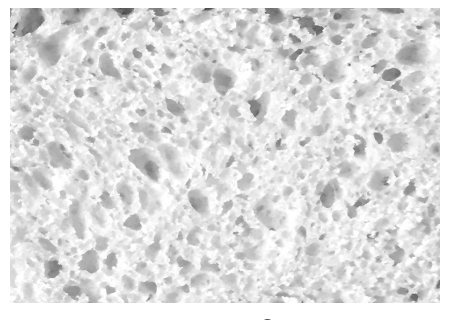

a

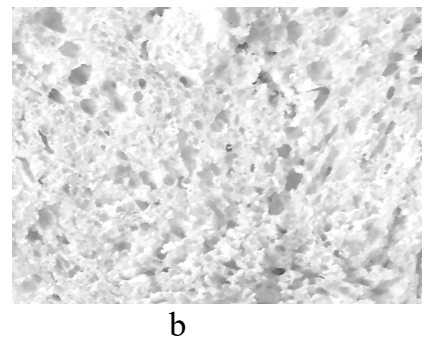

$\mathrm{b}$

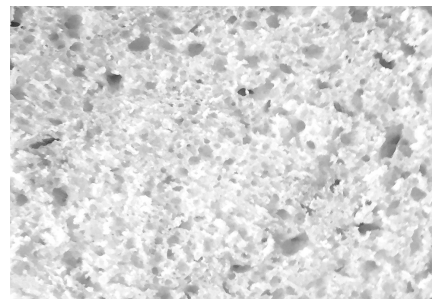

$\mathrm{C}$

Fig. 3 - Specimens of bread with oils:

$\mathrm{a}$ - amaranth, $\mathrm{b}$ - maize, $\mathrm{c}-$ sunflower.

Table 2 - Organoleptic analysis of bread made of wheat flour with various vegetable oils

\begin{tabular}{|c|c|c|c|}
\hline \multirow{2}{*}{ Features } & \multicolumn{3}{|c|}{ Results of test } \\
\hline & Specimen 1 -amaranth & Specimen $2-$ maize & Specimen 3 - sunflower \\
\hline Appearance & $\begin{array}{c}\text { Smooth, no cracks, dam- } \\
\text { ages, deformations }\end{array}$ & $\begin{array}{c}\text { Smooth, no cracks, } \\
\text { damages, deformations }\end{array}$ & $\begin{array}{c}\text { Smooth, no cracks, } \\
\text { damages, deformations }\end{array}$ \\
\hline Shape & Accords with the sort & Accords with the sort & Accords with the sort \\
\hline Color & Pale yellow & $\begin{array}{c}\text { Pale yellow with } \\
\text { darker stains on crumb cut }\end{array}$ & Pale yellow \\
\hline Kneading quality & No flour clumps & No flour clumps & No flour clumps \\
\hline Crumb structure & $\begin{array}{c}\text { Elastic, uniformly porous, } \\
\text { no indurations. No sticki- } \\
\text { ness felt by touching } \\
\end{array}$ & $\begin{array}{c}\text { Elastic, non-uniformly po- } \\
\text { rous. No stickiness } \\
\text { felt by touching } \\
\end{array}$ & $\begin{array}{l}\text { Elastic, non-uniformly porous, } \\
\text { less pores in the central portion. } \\
\text { No stickiness felt by touching }\end{array}$ \\
\hline Crust & Brown, up to $3 \mathrm{~mm}$ & Dark-brown, up to $3 \mathrm{~mm}$ & Brown, up to $3 \mathrm{~mm}$ \\
\hline Flavor & $\begin{array}{c}\text { Full, accords } \\
\text { with the products }\end{array}$ & $\begin{array}{c}\text { Full, accords } \\
\text { with the products }\end{array}$ & $\begin{array}{c}\text { Full, accords } \\
\text { with the products }\end{array}$ \\
\hline Odor & $\begin{array}{c}\text { Rich, not strong, } \\
\text { accords with the product }\end{array}$ & $\begin{array}{l}\text { Rich, strong odor } \\
\text { of maize oil }\end{array}$ & $\begin{array}{c}\text { Rich, not strong, } \\
\text { accords with the product }\end{array}$ \\
\hline
\end{tabular}


Conclusions

1. Components of the amaranth oil increase the fermentative activity of Saccharomyces cerevisiae yeasts and accelerate the mechanisms of self-regulation and self-recovery.

2. The amaranth oil contains a rare ketoenolic form of vitamin $\mathrm{E}$ which can increase the elasticity of cell walls, intake of the substances into the cell and discharge of meatbolites, which, in turn, accelerates metabolism.

3. Biologically active substances of amaranth oil greatly enrich the nutrient medium and positively impact the development of fastidious lactic acid bacteria which accelerates the processes of dough maturation. In the specimen with amaranth oil, the process of dough maturation ended 20 min earlier than in two specimens with other vegetable oils, and 25 min earlier than in the control specimen.

4. Using yeasts activated by amaranth oil allows to accelerate the fermentation and maturation processes and highly improves some organoleptic features of the bread quality.

\section{REFERENCES}

1. Капрельяни Л. В. Мікробіологія харчових виробництв [Текст] / Л. В. Капрельяни, Л. М. Пилипенко, А. В. Сгорова та ін. // Херсон: ФОП Гринь Д.С., 2016. - 476 с.

2. Дробот В. І. Технологія хлібопекарського виробниитва [Текст] / В. І. Дробот // К.: Логос, 2002. - 365 c.

3. Шендеров Б. А. Медицинская микробная экология и функииональное питание [Текст] / Б. А. Шендеров // Том III : Пробиотики и функииональное питание. - М. : Изд-во ГРАНТЬ, 2001. -288 c.

4. Крюк Т. В. Сучасні методи експертизи харчових олій [Текст] / Т. В. Крюк, Р. С. Транковська // Наук. журнал ЛОГОS. «Мистеитво наук. думки». - Вип. 2, лютий 2019, - С. 46-49.

5. Чиркова Т. В. Амарант - культура ХХІ века [Текст] / T. В. Чиркова // СОЖ, 1999. - № 10.- C. $22-27$.

6. Chulak L. D. Ultrasonic estraction of amarant oils [Text] / L. D. Chulak, V. G. Zadorozhny, Yu. L. Chulak, O. L. Chulak, O.V. Tatarina // Journal of Education, Health and Sport. 2018: 8 (8): 1223-1232. DOI: 10.5281/zenodo.1465021

7. Килименчук Е. А. Биотехнологические аспекты получения кисломолочного продукта функиионального назначения [Текст] // Е. А. Килименчук, М. И. Охотская, Г. И. Евдокимова // Харчова наука і технологія, 2015. - № 3. - T. 9. C. 14-18. DOI: $10.15673 / 2073-8684.3 / 2015.50274$

8. Килименчук О.О. Застосування олії амаранту при вирощуванні Lactobacillus plantarum [Tекст] / О. О. Килименчук, M.I. Охотська, Г. Й. Свдокимова // Наук. пр. ОНАХТ, 2015. - Bun. 48. - C. 88-93. DOI:10.15673/swonaft.v0i48.793

9. Килименчук О. О. Методичні вказівки до виконання лабораторних робіт з дисципліни «Технічна мікробіологія. Частина 2 (спецкурс)» для студентів спеціальності 181 «Харчові технології та інженерія» освітньої програми підготовки «Технологічна експертиза та безпека харчової продукції» денної та заочної форм навчання / Уклад.: О. О. Килименчук, А. В. Сгорова, Л. В. Труфкаті, Н. О. Швець. - Одеса: ОНАХТ, 2016. - 71 с.с. А.А. Уманець, А.Д. Гніліченко, Г.О. Проданова, студенти СВО «Бакалавр», фак-ту ТВтаТБ Т.О. Велічко, канд. техн. наук, доцент Одеська національна академія харчових технологій, м.Одеса, Україна

\section{ВИВЧЕННЯ ОКРЕМИХ БІОТЕХНОЛОГІЧНИХ АСПЕКТІВ ПРОЦЕСУ БРОДІННЯ ПШЕНИЧНОГО ТІСТА}

\section{Анотація}

В статті наведено результати дослідження поведінки дріжджових клітин Saccharomyces cerevisiae y проиесі бродіння пшеничного тіста з різними рослинними оліями, а саме, амарантовою, соняшниковою та кукурудзяною. Проведено підрахунок дріжджових клітин та вивчення їхніх фізіологічних особливостей на різних етапах процесу бродіння хліба з пшеничного борошна. Досліджено динаміку зміни кислотності у процесі бродіння та дозрівання тіста титрометричним методом.

Результати досліджень свідчать, щ⿻о процес адаптації дріжджової клітини до поживного середовищза відбувається швидше у присутності олії амаранту порівняно з кукурудзяною та соняшниковою рослинними оліями. Компоненти олії амаранту підвищують бродильну активність дріжджів Sассhаromyсеs cerevisiae. 3 a рахунок дії активних інгредієнтів олії амаранту значно швидше відбувається процес активації дріжджів, включаються механізми саморегуляиії та самовідновлення, прочеси бродіння та дозрівання скорочуються, якість хліба, отриманого безопарним способом, покращується. Активаџія дріжджових клітин при бродінні тіста з додаванням амарантової олії можлива за рахунок насичення поживного середовища додатковим киснем за рахунок сквалену, щзо діє на початку процесу адаптації клітини до поживного середовища. В такому середовищі значно швидше включаються механізми саморегуляиії та самовідновлення.

Окрім сквалену в олї амаранту міститься рідкісна токотриенольна форма вітаміну Е, яка здатна підвищувати еластичність стінок клітин, проникність речовин у клітину і виведення метаболітів з неї, щзо прискорюе процеси метаболізму.

Біологічно активні речовини олії амаранту значно збагачують поживне середовище і позитивно впливають на розвиток вибагливих до поживних середовищ молочнокислих мікроорганізмів, щзо прискорює процеси дозрівання тіста. Процес дозрівання тіста скорочується на 20 хвилин. 
Використання активованих амарантовою олією дріжджів дозволяє покращити окремі органолептичні показники хліба. Оптимізовано дозу амарантової олії, та розроблено рецептуру хліба з пшеничного борошна.

Ключові слова: дріжджі, бродіння, кислотність, рослинні олії, амарант, сквален, поживне середовищее, активація.

\title{
ЛIТЕРАТУРА
}

1. Капрельяни Л. В. Мікробіологія харчових виробництв [Текст] / Л. В. Капрельяни, Л. М. Пилипенко, А. В. Сгорова та ін. // Херсон: ФОП Гринь Д.С., 2016. - 476 с.

2. Дробот В. І. Технологія хлібопекарського виробництва [Текст] / В. І. Дробот // К.: Логос, 2002. - 365 c.

3. Шендеров Б. А. Медицинская микробная экология и функциональное питание [Текст] / Б. А. Шендеров // Том III : Пробиотики и функииональное питание. - М. : Изд-во ГРАНТЬ, 2001. - 288 c.

4. Крюк Т. В. Сучасні методи експертизи харчових олій [Текст] / Т. В. Крюк, Р. С. Транковська // Наук. журнал ЛОГОS. «Мистеитво наук. думки». - Вип. 2, лютий 2019, - C. 46-49.

5. Чиркова Т. В. Амарант - культура ХХІ века [Текст] / Т. В. Чиркова // СОЖ, 1999. - № 10.- C. 22-27.

6. Chulak L. D. Ultrasonic estraction of amarant oils [Text] / L. D. Chulak, V. G. Zadorozhny, Yu. L. Chulak, O. L. Chulak, O.V. Tatarina // Journal of Education, Health and Sport. 2018: 8 (8): 1223-1232. DOI: 10.5281/zenodo.1465021

7. Килименчук Е. А. Биотехнологические аспекты получения кисломолочного продукта функиионального назначения [Текст] // Е. А. Килименчук, М. И. Охотская, Г. И. Евдокимова // Харчова наука і технологія, 2015. - № 3. - T. 9. C. 14-18. DOI: $10.15673 / 2073-8684.3 / 2015.50274$

8. Килименчук О. О. Застосування олї̈ амаранту при вирощуванні Lactobacillus plantarum [Текст] / O. О. Килименчук, М. І. Охотська, Г. Й. Євдокимова // Наук. пр. ОНАХТ, 2015. - Вип. $48 . \quad$ С. $88-93$. DOI:10.15673/swonaft.v0i48.793

9. Килименчук О. О. Методичні вказівки до виконання лабораторних робіт з дисиипліни «Технічна мікробіологія. Частина 2 (спечкурс)» для студентів спеціальності 181 «Харчові технології та інженерія» освітньої програми підготовки «Технологічна експертиза та безпека харчової продукції» денної та заочної форм навчання / Уклад.: О. О. Килименчук, А. В. Сгорова, Л. В. Труфкаті, Н. О. Швеиь. - Одеса: ОНАХТ, 2016. - 71 с.с.

Надійшла 22.03.2019. Рецензія 15.04.2019.

До друку 07.06.2019.

Адреса для переписки:

112 Kanatna Str., 65039 Odesa, Ukraine,

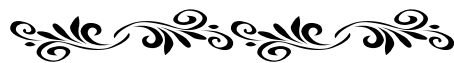
kylymenchuk@gmail.com

\section{THE CHARACTERISTIC OF COMPOUND FEEDS FOR TILAPIA FISH}

\begin{abstract}
The article states that, according to the literature review, in aquaculture of freshwater fish species that acquire everincreasing production volumes, tilapia is leading with $17 \%$, and it is follower by carp (15\% of world volume). For almost 60 years, tilapia have moved into second place in the global fish production, with the prospect of taking first place in the next 2-3 years and overtake carp in world production. Since fish is a rich source of proteins and essential amino acids, vitamins, polyunsaturated fatty acids, macro and micronutrients, it is also an important component of the diet of the population. Meat of tilapia is dense, non-fat, protein content close to trout meat, does not contain intermuscular bones. One of the priorities of the development of fish farming in Ukraine is the cultivation of tilapia. The amount of feed consumption in the world is increasing every year, due to the rapid growth in demand for tilapia. Currently, Ukrainian businessmen are interested in the production of catfish and tilapia. The most famous aquapride plants that grow these breeding objects are Lauren Aquaculture LLC (Rivne region), Aqua System Organic LLC (Kiev region), Catfish from Pavlysh TM (Kirovograd region), TM "First City Fish Farm 'I want a catfish "(Kiev). That is why the production of balanced domestic feed for tilapia is an important task of the feed industry of Ukraine. The theoretical study was devoted to the issue of tilapia feed production. The nutritional value of feed for tilapia depends on the stage of the life cycle of this species of fish. It was shown the world leading manufacturers of feed for tilapia, it was analyzed the nutritional value of feed for this species of fish on the content of crude protein in the starting, growth and finishing periods, respectively. The requirements for the content of essential nutrients, essential amino acids, minerals (micro and micronutrients), water-and fat-soluble vitamins and restrictions on the content of crude fiber are given. The programs of feeding of tilapia of various producers are analyzed and an own program of feeding this species of fish is developed, it is divided the starting, growth and finishing period of tilapia growing. For starter mixed feeds for tilapia, the content of crude protein should be at least $45 \%$, crude fat at least $12 \%$, crude fiber not more than $1.5 \%$, gross energy not less than $18 \mathrm{MJ}$, crude ash not more than $8 \%$. For grower's feeds, the content of crude protein should be at least $40 \%$, crude fat at least $12 \%$, crude fiber not more than 3\%, gross energy not less than $17 \mathrm{MJ}$, crude ash not more than $9.5 \%$. For finishing feeds, the content of crude protein should be at least $30 \%$, crude fat at least $6 \%$, crude fiber not more than $5 \%$, gross energy not less than $17 \mathrm{MJ}$, crude ash not more than 7\%. Amino acids requirements are very important for tilapia fish, feeds for tilapia from any period should contain lysine should be at least $1.6 \%$, methionine should be at least $0.7 \%$.
\end{abstract}

Key words: compound feed for tilapia fish, feed manufacture technology for tilapia fish feeds, nutritional requirements for tilapia fish feeds. 